\title{
Poststructuralist ethics: subjectivity, responsibility and the space of community
}

\section{E. Jeffrey Popke}

Department of Geography, East Carolina University, Greenville, NC 27858, USA

\begin{abstract}
The theoretical tenets of poststructuralism pose significant challenges to traditional ethical thinking, suggesting the need for an ethics sensitive to openness and difference. Drawing upon the work of Levinas, Derrida and Nancy, I discuss three dimensions of such an ethics: a theory of subjectivity based in a responsibility to the other; a politics of deconstruction within which this responsibility is foregrounded; and a theory of spatiality articulated in the sharing of community. This points toward an ethics of hospitality, in which the space of community is offered as a gift, and in the context of an irrecusable responsibility toward others.
\end{abstract}

Key words: ethics, poststructuralism, space, deconstruction, politics, community, Levinas, Derrida, Nancy.

\section{Introduction}

Over the past decade or so, the broad currents of thought variously labeled postmodernism, poststructuralism and deconstruction have had a significant, and I believe salutary, impact upon the theory and practice of human geography. Drawing on a diverse range of theories, and deploying a wide array of conceptual tools, such work has opened up new lines of inquiry into the spatiality of social life. For proponents of such approaches, poststructuralist theory offers the potential to break down existing categories of power and knowledge, and thereby to foster alternative narratives, which have the potential to widen the scope and scale of our geographical imaginations.

At the same time, we have witnessed within geography a proliferation of work dealing with issues of ethics, morality and justice. Building on the pioneering work of David Smith, Jim Proctor and others, geographers have begun to explore a wide range of moral and ethical concerns, focusing in particular on the ways in which such concerns intersect with material and symbolic geographies. To date, however, there has been little explicit engagement between these two currents of thought. I find this silence 
striking because, in a number of ways, poststructuralist understandings of politics, subjectivity and space pose significant challenges to those of us who wish to cultivate an ethical geographical praxis. In part, this lack of engagement can be explained by a common association of poststructuralist approaches with a form of relativism, or nihilism, which would render ethical accounts impossible. Recently, however, a number of innovative attempts have been made to link the anti-foundational position of poststructuralism to a form of ethics grounded in a responsibility for distant others. These accounts, I believe, have important implications for theorizations of space and place in a world that continues to search for moral and ethical bearings.

In this essay, then, I explore some of the implications of poststructuralism for thinking ethics spatially. I focus in particular on the philosophical arguments of Emmanuel Levinas, Jacques Derrida and Jean-Luc Nancy who, in different ways, articulate forms of ethics and justice that move beyond traditional conceptions of subjectivity and space. Taken together, I argue, this work suggests an ethics grounded in a responsibility toward distant others, and a politics in which that responsibility is brought to the fore. This work also suggests alternative understandings of spatiality, with implications for the practice and performance of human geography.

\section{The postmodern challenge to ethics}

In 1988, Michael Dear suggested that 'there is no more important task for contemporary human geography than to confront the ontological and epistemological challenges posed by the post-modern movement' (p. 267). I think it fair to say that, over the past decade, this challenge has been taken up (if not resolved) in a number of important ways within geography's theoretical debates. Although a full accounting of these debates is not possible here (see Peet, 1998; Dear, 2000), it is clear that the intellectual ferment they have engendered has had a significant impact upon the theory, focus and methodology of geography. Perhaps the overriding sentiment within this work is a widely noted 'distrust of metanarratives' governing theoretical systems, and a healthy skepticism toward the universality of truth and knowledge claims. This has helped to focus attention on the role of language, convention and positionality in the production of meaning, and on the social and discursive framing of taken-for-granted categories and objects of inquiry.

From an empirical perspective, these insights have provoked a re-examination of geographical phenomena in a wide range of domains, with emphasis increasingly placed upon the ways in which social meanings and categories take on the appearance of truth or objectivity. Recent work has examined, for example, the discourses governing geopolitics (Ó Tuathail, 1996; Ó Tuathail and Dalby, 1998), the economy (Barnes, 1996; Gibson-Graham, 1996), urban space (Soja, 1996; Dear, 2000), colonialism and development (Jacobs, 1996; Yapa, 1996), the environment (Braun and Castree, 1998) and the nature of identity, particularly the spatial structuring of gender/sexual and racial/ethnic difference (Sibley, 1995; Dwyer and Jones, 2000; Nast, 2000).

The poststructuralist intervention has also prompted a series of philosophical debates, which have posed a challenge to traditional understandings of metaphysics and epistemology. In this more theoretical vein, poststructuralism offers a critique of logocentrism, the centering or grounding of claims to truth or objectivity (Dear, 1988; 
Doel, 1992; Barnes, 1994; Dixon and Jones, 1998). From this perspective, the apparent stability of meaning embedded in any system of thought is potentially destabilized by elided traces of difference, and by the multiple contexts in which knowledge is produced, received and interpreted. As Strohmayer and Hannah (1992: 36) put it, 'the truth of any statement, scientific or otherwise, which ultimately must rely on some anchoring in order to avoid being completely arbitrary, is undecidable.'

This 'deconstruction' of universals poses a significant challenge to traditional understandings of ethics, for the anti-foundational stance of poststructuralism implies that any project aimed at defining an ethics, or a normative theory of society, would be doomed to failure. From a poststructuralist perspective, universal claims to knowledge and truth can become a barrier to fostering a sensitivity to difference, and thus ethics would need to find its purchase in the radical instability of meaning and the deconstruction of universal normative claims. The goal of such an anti-essentialist approach, as David Slater (1997: 69) has noted, is to cultivate a 'political openness, or an "ungrounded ground", where foundations or norms or universal prescriptions only exist to be put into question as a permanent feature of the process of democratization'. Some commentators have gone so far as to suggest that we should take up a position against ethics, in the sense of a model of moral or ethical actions, and instead work to foster 'an ethics of encounter without a commitment to resolution or closure' (Campbell and Shapiro, 1999a: xi, xvii; see also Caputo, 1993). I will try below to suggest how we might imagine such an 'ethics of encounter', but first I turn to examine some of the responses within geography to the postmodern challenge to ethics.

\section{Ethics and geography}

It may seem paradoxical that while calls are being made to be 'against ethics' examinations of a moral or ethical nature appear to be flourishing within geography. The publication of a number of recent volumes dealing with geography and ethics attests to this interest (e.g., Low, 1999; Procter and Smith, 1999; Smith, 2000). Largely through an engagement with moral philosophy and political theory, this work has highlighted the moral and ethical implications of geographical representation and practice in such areas as environment and landscape (Faulstich, 1998; Ethics, Place and Environment, 2001a; Smith, 2001; Howitt, 2002); human rights and social justice (Harvey, 1996; Low and Gleeson, 1999); globalization, geopolitics and development (Slater, 1997; Young, 1999; Wood, 2000); and the ethics of the research process (Hay, 1998; Ethics, Place and Environment, 2001b). This work has made important contributions to the discipline of geography, by bringing to light the often unstated ethical implications of our theories, and by continuing to place issues of justice, rights and ethics on the geographical agenda. At the same time, geographers have contributed to moral and ethical theory, by calling attention to the spatial implications of our moral and ethical commitments.

Perhaps the overriding sentiment within this work has been a concern to interrogate the common tendency to privilege the local over 'distant strangers'. How, in other words, can we activate a form of responsibility to those with whom we have no direct social interaction, to challenge the 'out of sight, out of mind' mentality that would appear to be a feature of our geographical experience? Most responses to this question begin with some notion of human commonality. Smith (2000: 42), for example, asserts 
that 'morality ... has its roots in the facts of human dependency and connectedness, in the inescapably social nature of human existence'. Such an argument would appear to have increased purchase in the contemporary world, in which the globalization of economic activity and the movement of people have increased the interconnectedness between local and distant strangers (Corbridge, 1998). Others have attempted to elaborate a 'new universalism' (Low and Gleeson, 1999), or 'a certain kind of universalism' (Harvey, 2000), which could provide the grounding for an ethical responsibility that holds for those who are spatially distant. Corbridge (1994: 110), for example, avers that he is 'not willing to deconstruct further certain minimally universalist claims, of the type that involuntary death from hunger, or involuntary malnutrition, or involuntary homelessness, or slavery, or torture are bad things which must be struggled against'.

Given this concern with articulating geographically universal principles for normative conduct, it is perhaps not surprising that there has thus far been little explicit response to 'the postmodern challenge' to ethics. To the extent that the issue is addressed, it has often been in the form of a deep skepticism. Unwin (1999: 271), for example, suggests that if reduced to the extreme, the relativist stance can lead to a position where individual expression is all that matters, and to a view of society in which anything is accepted'. In addition David Smith (2000: 101), in his most extensive comments on the issue of postmodernism, writes as follows:

Insofar as postmodern thinking is relevant to such a grand question as the spatial scope of care, it is likely to encourage parochialism. The stress on difference and particularity, while drawing attention to the specific needs of various groups of hitherto marginalized 'others', dilutes the force of an argument from human sameness or similarity, which supports spatially extensive responsibility for people who are like ourselves in morally significant respects ... the moral relativism (or nihilism) encouraged in some postmodern thinking is far from politically benign; instead of being merely an intellectual indulgence of the well-to-do, this perspective helps to entrench their privilege.

Although I am sympathetic with the impulse behind such sentiments, I think that Smith mischaracterizes the nature of 'postmodern thinking', and I would suggest that a deeper engagement might be possible between the concerns of poststructuralism and geographical ethics. This engagement would reject any normative ground for ethical conduct, not in order to evade our responsibility to distant others, but rather because foundational normative theories provide the means by which our ethical responsibility can be elided. From this perspective, the deconstruction of universalist conceptions of rights, ethics and justice should be viewed as a means of opening possibilities, rather than closing them. In what follows, I want to elaborate on this perspective, focusing attention on three areas in particular: the nature of the subject, the question of politics, and the ways in which these imply particular understandings of space.

\section{Rethinking the subject}

Most renditions of moral or ethical theory have their roots in Enlightenment thinking, when the decentering of the authority of God and monarch placed human individuals at the center of the social world, and thus provided the possibility for an ethics that would be based upon human reason and agency (Venn, 2000). The locus of this agency is the Cartesian subject, endowed with autonomy and rationality, and thereby capable of making moral decisions. There are two dimensions in particular of this modern 
subjectivity that are worth highlighting here. First, the modern subject's coherence and autonomy has been managed and maintained through repeated attempts to define, categorize and classify a range of deviant 'others'. Modern notions of autonomy and agency, in other words, have been dependent upon the specification and control of difference (ethnic, racial, gender, class, etc.), against which the positive identity and self-image of the (western, male) Enlightenment subject could be maintained. The birth of the modern subject, in this sense, is tightly bound up with the processes of colonialism, industrialization and governmentality through which certain kinds of difference were made to matter in both conscious and, perhaps especially, unconscious ways (Pile, 1996; Wilton, 1998; Venn, 2000).

The second and related point is that the ways in which these various axes of identity/difference have been mobilized are fundamentally spatial. Modern subjectivity is not only inscribed through a dualism between self and other, but also between here and there, via the spatialization of inclusion and exclusion, presence and absence, and the specification of what is 'in-place' and 'out-of-place' (Shields, 1992; Sibley, 1995; Cresswell, 1996; Kirby, 1996). The Cartesian subject is interpellated within a metaphysics of spatial presence - in Heidegger's terms, Dasein, or being-there - and circumscribed by a location or place from which it can negotiate the world. Derrida (1994a: 82) has referred to this metaphysics as ontopology, 'an axiomatics linking indissociably the ontological value of present-being to its situation, to the stable and presentable determination of a locality, the topos of territory, native soil, city, body in general'.

In sum, the subject of modern ethics is a subject fundamentally constituted through the maintenance of boundaries, both social and spatial. Partly for this reason, much modern ethical thought has focused concern on those distant others who are located 'on the other side of the boundary'. Indeed, as Zygmunt Bauman (1991: 59) has noted, within the modern spatialization of subjectivity, the figure of the stranger becomes the prototypical ethical problem, because the stranger is ... someone who refuses to remain confined to the "far away" land or go away from our own and hence ... defies the easy expedient of spatial or temporal segregation.' In a similar vein, Michael Dillon (1999) has argued that the refugee, existing outside of ontopolitical borders, has come to represent 'a scandal' for modern political subjectivity, calling into question the nature of political and ethical conduct.

The typical response to such problems has been to endow the autonomous subject with a set of rights, which can be legally enforced within the boundaries of political jurisdiction. One of the most important figures in this conception of ethics is Kant, who believed that the project of modernity could be universally extended for the benefit of humankind through the application of reason and judgment (Shapiro, 1998). Kant's philosophy, as Walker (1999: x) notes, was an 'attempt to internalize the law of reason, to develop the autonomous rationality, the mature personality realizable within each individual so that it might act in accordance with some universal moral norm'.

Importantly, Kant viewed this 'universal norm' arising from the spatial interconnections between different parts of the world, which necessitated a 'cosmopolitical right' that would guarantee conditions of 'universal hospitality'. Kant writes (1939: 27):

[due to] the connections, more or less near, which have taken place among the nations of the earth, having been carried to that point, that a violation of right, committed in one place, is felt throughout the whole, the idea of a cosmopolitical right ... is the last step of perfection necessary to the tacit code of civil and public right. 
For Kant, this notion of a 'public right' was 'founded upon a federation of free states' (1939: 18), and thus depended upon a bounded notion of state citizenship. These two notions - the autonomous subject of political reason and the territorialization of the state system - have come to define contemporary politics based upon an epistemology of sovereignty.

Recent work in international relations theory has posed significant challenges to this conception of sovereignty, politics and space (Edkins et al., 1999; Campbell and Shapiro, $1999 b)$. Rather than accepting state territorialization and citizenship as natural, such work suggests that we view it as part and parcel of the philosophical infrastructure of modernity. As Shapiro notes (1999: 60), our understandings:

tend to be constructed within a statecentric, geostrategic cartography, which organizes the interpretation of enmities on the basis of an individual and collective national subject and cross-boundary antagonisms. Ethical approaches aimed at a normative inhibition of these antagonisms continue to presume this same geopolitical cartography.

One of the provocations of poststructuralism would be to call into question this conception of subjectivity and space, to follow Jean-Luc Nancy (2000: 136) in asserting that 'in order to think the spacing of the world . . . the end of sovereignty must be faced head-on'. It is in this sense that Whatmore (1997) has called for a 'dissecting of the autonomous self' in order to promote a 'relational ethics' (see also Cloke, 2002). We need, as David Slater (1997: 68) puts it, to 'rethink what we might mean by responsibility to otherness. This responsibility can be linked to a notion of radical interdependence, in which the ethics of intersubjectivity are in the foreground.'

\section{Responding to the other}

In order to suggest what such an ethics might look like, I draw upon the work of Emmanuel Levinas, whose philosophy articulates an ethics and subjectivity that breaks sharply from the bounded Cartesian model. For Levinas, ethics arise first and foremost out of our fundamental responsibility for the other. Indeed, he posits that our subjectivity is nothing other than this pre-ontological relation to alterity: 'my ethical relation of love for the other stems from the fact that the self cannot survive by itself alone, cannot find meaning within its own being-in-the-world, within the ontology of sameness ...' (Levinas and Kearney, 1986: 24).

For Levinas, this position entails more than the important recognition that human lives are lived in social interaction with others. It signals an ethics of intersubjectivity, which Levinas calls 'first philosophy', prior to any social mediation or philosophical system (Levinas and Kearney, 1986: 23):

The ethical exigency to be responsible for the other undermines the ontological primacy of the meaning of being; it unsettles the natural and political positions we have taken up in the world and predisposes us to a meaning that is other than being, that is otherwise than being.

In this sense, the other calls forth in us a form of ethical responsibility that would be unconditional, beyond any 'political position' and outside of any social or geographical context. As a feature of our subjective being, the other does not refer to any specific individual, but rather to the anonymous call of the other, what Levinas describes as a 
'face'. Our ethical responsibility is thus not bound to a cultural context; the face signifies beyond any social meaning that might be implied by race, gender, ethnicity, etc. 'The face,' writes Levinas, is 'signification without context. I mean that the Other, in rectitude of his face, is not a character within a context . . f face is meaning all by itself' (Levinas, 1985: 86). That the face is 'signification without context' does not mean that our ethical responsibility is merely hypothetical or abstract. For Levinas, our engagements with the other are always concrete - embodied and emplaced - but in a relationship that is prior to any significance that might be attached to it by philosophy, culture, politics or place (Howitt, 2002).

This latter point has implications for any geographical consideration of ethics. For Levinas, the face is not a particular being in time and space, but approaches me as an immediate demand, a sensibility that Levinas calls 'proximity'. Proximity here does not refer to a sense of Cartesian distance, but rather to the immediacy of the responsibility demanded by the face. As Levinas puts it (1985: 96), 'the other is not simply close to me in space, or close like a parent, but he approaches me essentially insofar as I feel myself - insofar as I am - responsible for him'. Thus, our responsibility cannot be dependent upon our spatial location, or upon the 'community of fate' into which we are born (Smith, 2000). In the presence of the face, 'I am . . . open to an accusation of which no alibi, spatial or temporal, could clear me' (Levinas, 1989: 83).

The ethical relationship, in this sense, is not diminished by the contingencies of geographical location. Our responsibility is unconditional, and holds equally to those who are 'distant' as those who are near. For Levinas, this responsibility arises because there is a certain form of violence involved in the 'taking place' of being. As Levinas puts it (1989: 82):

my being-in-the-world or my 'place in the sun', my being at home, have these not also been the usurpation of spaces belonging to the other man whom I have already oppressed or starved, or driven out into a third world; are these not acts of repulsing, excluding, exiling, stripping, killing?

This does not mean that our ethical responsibility stems from any direct culpability, in which my actions could be proven to have caused the suffering of the other. It is, rather, an ontological claim, that my being is always-already an occupation of the world, or a form of trespass, which impinges on the other (Cloke, 2002): 'it is the fear of occupying someone else's place with the $D a$ of my Dasein' (Levinas, 1989: 82). We thus incur an unpayable debt to the other, which is etched in the structure of alterity, and through which we are granted our very right to be. It is 'a responsibility that goes beyond what I may or may not have done to the Other or whatever acts I may or may not have committed, as if I were devoted to the other man before being devoted to myself' (Levinas, 1989: 83).

\section{From ethics to rights and justice}

Levinas's radical reconfiguration of subjectivity has implications for traditional theories of ethics and rights. In posing subjectivity as a responsibility to the other, he undermines the Kantian subject's sovereignty and thus calls into question the dominant juridical foundations for determining ethical conduct. If the account I have given, however, provides a possible model of subjectivity and responsibility, it would seem to 
work decidedly less well as a description of ethical motivation and conduct. Given the widespread inequality, injustice and brutality of our contemporary world, the claim that we bear responsibility for the other before ourselves may appear as nothing more than a utopian longing. Indeed, Levinas himself was equivocal on this point, admitting that 'as prima philosophia, ethics cannot itself legislate for society or produce rules of conduct whereby society might be revolutionized or transformed' (Levinas and Kearney, 1986: 29). Elsewhere, he suggests that 'there's a direct contradiction between ethics and politics, if both of these demands are taken to the extreme' (Levinas, 1989: 292).

This contradiction is most clearly evident in Levinas's discussion of justice. As we have seen, Levinas posits a theory of subjectivity in which we have a responsibility for (the face of) the other. In our social interactions, however, we are presented with a plurality of others, such that we must mediate our various responsibilities. This, for Levinas, is the realm of politics and justice (Levinas and Kearney 1986: 21-22):

if there were only two people in the world, there would be no need for law courts because I would always be responsible for, and before, the other. As soon as there are three, the ethical relationship with the other becomes political and enters into the totalizing discourse of ontology. We can never completely escape from the language of ontology and politics.

In our everyday interactions with others, ethical responsibility is mediated by what Levinas calls 'the political world of the impersonal "third" - the world of government, institutions, tribunals, schools, committees, and so on' (Levinas and Kearney, 1986: 29). Ultimately, because our social life cannot be guided by our one-to-one responsibility for any particular other, we must make choices (Levinas, 1994: 45):

\footnotetext{
I have also to answer for the third party 'next to' my neighbor. But who is next to whom? The immediacy of my relation to my neighbor is modified by the necessity of comparing persons with one another and judging them. Recourse to universal principles, locus of justice and objectivity.
}

Levinas is here traversing the difficult move from the realm of intersubjective ethics to that of politics, in which we must make decisions, render judgments, and negotiate alternatives.

Yet Levinas's answer to this dilemma is ultimately unsatisfying, for he defers this allimportant moment of decision to the certainty of 'universal principles'. For Levinas, like Kant, the 'locus' of such principles is the state. 'There is a certain measure of violence necessary in terms of justice,' he writes, 'if one speaks of justice, it is necessary to allow judges, it is necessary to allow institutions and the state; to live in a world of citizens, and not only in the order of the Face to Face' (1998: 105). Elsewhere (1991: 19), Levinas suggests that '[a] just society has judges, and this society with judges has an army, and so on. And so we reach the liberal state, the state which always asks itself whether its own justice really is justice.' While Levinas provides an alternative way of thinking about subjectivity, he falls back upon an essentially Kantian conception of the State as guarantor of rights and justice. Responsibility in the political terrain, it would seem, is dependent upon state sovereignty and borders, up to and including a legitimate use of violence.

A number of commentators have addressed this aspect of Levinas's thought, and it has been suggested that it may be possible to extrapolate from his ethics an alternative conception of justice and the state (Perpich, 1998; Wingenbach, 1999; Drabinski, 2000). 
As Levinas himself (1985: 90) argued, 'justice, exercised through institutions, which are inevitable, must always be held in check by the initial interpersonal relation'. But he was never explicit about the mechanism by which ethical responsibility toward the other might translate into a moral state-form. At the very least, it can be said that Levinas's recourse to a metaphysics of sovereignty, where political negotiation presupposes territorial citizenship and the political autonomy of a sovereign state, stands in tension with his call for an intersubjective ethics. This is because the application of 'universal principles' as a mediator of politics always carries the potential to relieve us of our responsibility for our judgments and decisions. For, when we can simply rely upon the application of rules and norms, our accountability to the other becomes elided in the universality of a politics and ethics based in the juridical norms of law and the state. What is needed, then, is a different conception of the political, within which our responsibility to the other can be foregrounded. Here, I want to turn to the work of Jacques Derrida, in order to suggest that deconstruction can provide one means of activating a spatial responsibility to alterity.

\section{The politics of deconstruction}

Within geography's increasing engagement with poststructuralist theory, there have recently been a number of discussions of deconstruction (see Barnett, 1999). Most accounts describe deconstruction as a means of exposing the paradoxes, contradictions and elisions which undermine the purported coherence of philosophical or conceptual systems (Dear, 1988; Barnes, 1994). Others have drawn on deconstruction to consider the importance of context in the creation of meaning and interpretation (Dixon and Jones, 1998; Barnett, 1999).

For the most part, these authors draw upon Derrida's early works, and especially those dedicated to writing and textuality (e.g., Derrida, 1976; 1988). Taken together, they suggest that deconstruction can be seen as a form of intervention, a strategy to highlight the instability of meaning, and thereby to multiply the potential for alternative understandings. As Doel (1994: 1051) puts it, 'deconstruction affirms a movement of perturbation, turmoil, and dislocation ... [it] is the affirmation of destabilization on the move'. Although this destabilizing impulse is undoubtedly important, I want to suggest that deconstruction can be given a more political, and hence ethical, inflection than many authors do. In a series of more recent texts, Derrida has suggested that deconstruction's movement of destabilization can serve as both a critique of the normative foundations of international law and politics and also a means of addressing our responsibility for the other. Indeed, Derrida (1990: 945) has made the provocative claim that 'deconstruction is justice'.

We can begin to unpack this by noting that, within the discourses of modernity, the political has become circumscribed, limited to a discrete set of institutional practices, which are themselves supported by juridical and territorial norms. Deconstruction's ethico-political purchase then, like its philosophical effect, is a result of an intervention that aims to destabilize the grounds of authority for these norms, to show that law, constitution, state territorialization, human rights and so on are ultimately founded on what Derrida (1990: 943) terms a 'violence without ground'. For this reason, Derrida notes, law, like any system of grounding or authority, is inherently deconstructible. 
Deconstruction, by destabilizing the grounds of authority for international politics, opens the terrain to a new definition of the political, which would move beyond the metaphysics of sovereignty. What is needed, Derrida (1999: 221) suggests, is:

a dimension of the political divested of everything which - for better but especially for worse, in our modernity - has welded the political to the ontological (in the first place, to a certain conception of effectivity or presentbeing of the universal cast in terms of the state, and of cosmopolitical citizenship or the International cast in terms of the Party).

This 'ungrounding' of the political may appear as a form of nihilism, in which all arguments and positions have equal validity, leading to a condition of anarchy or political stasis. Yet I would suggest instead that deconstruction offers the potential to recast the political on the basis of our responsibility to respect the event of the decision. As Derrida puts it (1999: 240):

[political commitment] depends, at every instant, on new assessments of what is urgent in, first and foremost, singular situations, and of their structural implications. For such assessment, there is, by definition, no preexisting criterion or absolute calculability; analysis must begin anew every day everywhere, without ever being guaranteed by prior knowledge. It is on this condition, on the condition constituted by this injunction, that there is, if there is, action, decision and political responsibility - repoliticization [emphasis original].

The lack of any normative grounding for the decision does not mean that we need not decide. On the contrary, political responsibility is called for only because there is no way to guarantee the justness of the decision, because its outcome remains undecidable. Far from being a foreclosure of the political, then, the ethics of deconstruction would ' $r e$ politicize' or, as Derrida says elsewhere (1996: 85), hyper-politicize, disseminating the moment of political decision across infinite contexts (Derrida, 1995: 273):

if I speak so often of the incalculable and the undecidable it's not out of a simple predilection for play nor in order to neutralize decision: on the contrary, I believe there is no responsibility, no ethico-political decision, that must not pass through the proofs of the incalculable or the undecidable. Otherwise, everything would be reducible to calculation, program, causality.

This point is worth emphasizing: to assert that the decision is ultimately undecidable does not mean that there can be no such thing as truth, right or good. It means, rather, that if we purport to know in advance the specific content of such notions, then the event of the decision is divested of its political content, it is simply 'deduced from an existing body of knowledge ... [as] by a calculating machine' (Derrida, 1999: 240). Deconstruction, then, affirms the necessity to judge, to analyse, to make decisions, in the context of an event that is conditioned by our inexhaustible responsibility to the other (Derrida, 1997: 18):

That is what gives deconstruction its movement, that is, constantly to suspect, to criticize the given determinations of culture, of institutions, of legal systems, not in order to destroy them or simply to cancel them, but to be just with justice, to respect this relation to the other as justice [emphasis added].

A deconstructive ethics would in this way incite a political responsibility that first and foremost opens us to the (face of) the other, in which we surrender our sovereignty in 'a form of vigilant passivity to the call of the other' (Levinas and Kearney, 1986: 29).

This passive opening has been denounced by some as simply a form of 'patience' or 'tolerance' which justifies inaction. Thus Bridge (2000: 526) argues that, for Levinas, 'responsibility need not result in action' and Peet (1998: 242) charges that poststruc- 
turalism advocates 'a passive affirmation ... [that] waits for an-Other always to come that is, conveniently never there - so nothing ever needs doing in terms of political practice'. But I read the passivity of ethical responsibility differently, as a form of opening to limitless possibility in the absence of hubris, an orientation that derives, not from indifference, but from the recognition that 'I cannot calculate everything, predict and program all that is coming, the future in general, etc., and this limit to calculability or knowledge is also, for a finite being, the condition of praxis, decision, action and responsibility' (Derrida, 1999: 249). This responsibility is an exposure to the event, in its singular and incalculable context, through which the call of the other enjoins an ethics and politics of decision.

\section{Rethinking space}

I have thus far described a twofold move, which might form the basis for a poststructuralist ethics: first, a conception of subjectivity that is based in a responsibility toward the other and, second, a deconstructionist politics that would open us to the other's appeal. Each of these has implications for theorizing spatiality outside of the bounded, Cartesian model of sovereignty and ontopology. I want to turn, then, to examine some of the ways in which we might think about the space of an intersubjective ethics in the context of deconstruction.

We can usefully begin with David Campbell's (1998) admirable discussion of the ethical implications of the conflict in Bosnia. Drawing on both Levinas and Derrida to frame an argument similar to that presented here, Campbell suggests that the potential for ethical intervention in Bosnia, like so many other conflicts rooted in territorial claims, was foreclosed by a metaphysics of ontopology, in which the identities of the various Balkan ethnic/religious communities were seen to be rooted to certain bounded spaces. He calls for a form of deconstruction that would foster (Campbell, 1998: 208):

an appreciation of the role geographic (especially geopolitical) imaginaries have in shaping our political possibilities. The moral cartography enabled by the norm of ontopology has territorialized responsibility and bounded the possibility of ethical space in which encounters with alterity occur.

What is needed, he suggests, is a 'pluralization of sovereignty and space' combined with the 'deconstruction of identity' (p. 238). Campbell calls for a deconstructive 'ethos of democracy', an attitude of interminable critique, which would promote the principles of an always-open form of multiculturalism. Such an ethos 'embraces the temporality, oscillation, critique, disturbance, denaturalization, problematization - the "ad infinitum" of nomadic movements' (p. 202). Campbell's work is one of the finest attempts to trace the implications of a poststructuralist ethics for thinking about contemporary geopolitical change. He does not, however, discuss just how we should think about the 'pluralization of space' or the embrace of 'nomadic movements'. It remains, then, to suggest what a poststructuralist understanding of space might look like.

The most elaborate attempt at thinking such a spatiality has been put forward by Marcus Doel, in a series of innovative texts which seek to move beyond ontologies of sovereignty, presence and stasis. Drawing on the work of Derrida, Lyotard, Baudrillard and especially Deleuze, Doel sketches a view of space that is fractured and multiplied, impossible to capture or dam up in a single meaning: 'there are infinite infinities folded 
into each event of space and spacing' (1999: 3). For this reason, geography should be seen as a form of origami, for 'the world can be (un)folded in countless ways' (Doel, 1999: 18). Whereas the geographical tradition has relied upon a 'pointillism' which seeks to identify and contain spatiality, geography as origami would deterritorialize space, open space to its infinite displacements: 'it rigorously and obsessively opens out the folds of what is typically occluded and occulted by those approaches that would wish too hastily to force - i.e., feign - a decision, resolution, and destination' (1999: 131). In this view, space is far from a passive stage or container, but is radically open, constituted through perturbation, oscillation and movement: 'the composition of folds is not what something is, but rather what it is in the process of becoming, its becomingother, and its ceasing to be' (1999: 164). Put another way, 'what takes place unfolds and splays out ... place is nothing if it is not in process' (1999: 7).

This is undoubtedly an evocative spatial imaginary, one that deliberately resists any attempt at definition or closure. In this sense, Doel's 'vibratology' and 'schizoanalysis' are useful examples of taking seriously the spatial play of différance, of rethinking a relationship to spatiality that emphasizes its always-open constitution. With respect to ethics, however, Doel fails to offer us any means of thinking this opening in relation to responsibility and justice. When Doel writes that 'deconstruction ... affirms becoming through the re-release of difference, otherness, and alterity' (1999: 55), there is no elaboration of just how this alterity is to be respected, other than to maintain 'an openness to the event of space' (1999: 7):

letting space take place: that is the ambition of geography, when it is radical ... geography is simply an inclination towards the event of spacing ... our duty as geographers is simply to make space for the deforming force of alterity and to open up space to the differential currents of dissimulation, disjointure, and dissemination. Letting space take place. That is the ethic specific to poststructuralist geography $(1999: 10,198)$.

What is being described here is a passive affirmation, which eschews any form of territorialization or closure.

In the end, however, Doel offers an imaginary of spatial deconstruction which is devoid of the type of ethics and responsibility that I have advocated here. For the opening of space makes demands upon us, ethical and political, and thus our 'inclination towards the event' must be conditioned by our responsibility toward the other. If this responsibility is elided by universal formulations which are simply applied as a calculation, they are equally abrogated by an ethically agnostic form of passive individualism. It is not simply a matter, then, of 'letting space take place', but in thinking the space of the event as the means by which we affirm our subjectivity in and through the other. This means moving beyond the nomadic individualism of Deleuzian conceptualizations, toward a spatial imaginary grounded in intersubjectivity, responsibility and community. Here, finally, I turn to the work of Jean-Luc Nancy, who articulates a theory of space as opening, but one which also pays heed to the intersubjective nature of being.

\section{The ethical fold of community}

Nancy's philosophical writings articulate a project that resonates in some ways with the concerns expressed by Levinas. In particular, Nancy seeks to challenge the self-presence 
of the ' $\mathrm{I}$ ' of the egocentric subject, to question the 'ontology of subjectivity' that undergirds much of western philosophical thought (Nancy, 1993: 4). Whereas Levinas approaches this via the singular 'Other' for whom we are responsible, however, Nancy has been concerned to theorize subjectivity as a being-with, or a being-in-common, the locus of community: 'community means ... that there is no singular being without another singular being, and that there is, therefore, what might be called, in a rather inappropriate idiom, an originary or ontological "sociality" ' (1991: 28). In this sense, as Critchley (1999: 240) has suggested, Nancy's project can be read as a rewriting of Heidegger's Being and time, in which the concept of Mitsein (being-with) is foregrounded as a social ontology, and thus primary over Dasein.

Within this project, Nancy develops a view of space that moves beyond the metaphysics of presence, in which the $D a$ - of the egocentric subject is replaced by the Mit- of being-in-common. We need, he suggests, to 'think in principle about how we are "us" among us, that is, how the consistency of Being is in being-in-common, and how this consists precisely in the "in" or in the "between" of its spacing' (2000: 26). Freedom and autonomy, for Nancy, are not the properties of a bounded subject existing in Cartesian space, but instead the opening of space itself as a form of community, or sharing (Nancy, 1993: 70-71):

Freedom ... is not the struggle for recognition and self-mastery of a subjectivity. It is, from birth until death .. . what throws the subject into the space of the sharing of being ... Ontological sharing, or the singularity of being, opens the space that only freedom is able, not to 'fill', but properly to space. 'Spacing space' would mean keeping it as space and as the sharing of being, in order indefinitely to share the sharing of singularities. [emphasis original]

In this dense passage, Nancy articulates a spatiality that goes beyond Levinas's singular face or the nomadic individualism of Deleuzian conceptions, to consider the folding of the event of space as the locus of community. This would not be, however, a community that is constituted or present-to-itself, but an 'inoperative community', always in formation and always 'to come' (Nancy, 1991: 71):

there is no entity or hypostasis of community because this sharing, this passage cannot be completed. Incompletion is its 'principle,' taking the term 'incompletion' in an active sense, however, as designating not insufficiency or lack, but the activity of sharing, the dynamic, if you will, of an uninterrupted passage through singular ruptures. (Nancy, 1991: 35)

This sense of a community always-in-process resonates with Derrida's notion of 'democracy to come', a form of political responsibility that recognizes the open-ness of the political (Derrida, 1996: 83):

when I speak of democracy to come this does not mean that tomorrow democracy will be realized, and it does not refer to a future democracy, rather it means that there is an engagement with regard to democracy which consists in recognizing the irreducibility of the promise when, in the messianic moment, 'it can come'.

Derrida describes this 'engagement' as a form of messianic expectation, an absolute opening to the happening of the event as a disruption of the flow of time, an affirmation inseparable from a particular thinking of justice and responsibility: 'messianicity mandates that we interrupt the ordinary course of things, time and history here-now; it is inseparable from an affirmation of otherness and justice' (Derrida, 1999: 248-49).

Of course, this 'here-now' is not only temporal but spatial, and thus 'thinking about the event always opens up a kind of messianic space' (Derrida, 1994b: 32). Or, as Nancy 
(1993: 75, 78) puts it, "the political is the "spaciocity" ... of freedom ... [It] does not primarily consist in the composition and dynamic of powers ... but in the opening of a space'. This politics of opening to the messianic space of the event is community itself, based in the ontological sharing of existence: 'it is here, in this suspension [of time], that the communionless communism of singular beings takes place. Here takes place the taking place (which is itself without a place, without a space reserved for or devoted to its presence) of community' (Nancy, 1991: 72). This ethical taking place of space, which is the space of politics, justice and responsibility, cannot be anticipated, calculated or planned, but must be offered, as a 'gift of a spatio-temporality' (Nancy, 1993: 145). This would not simply be a 'letting space take place'; it would be rather a giving-place for community, a gift of hospitality to the other-in-oneself in the condition of our beingtogether in an unachievable community.

\section{$X$ Ethics, responsibility and the practice of human geography}

The philosophical claims of Levinas, Derrida and Nancy pose significant challenges to traditional understandings of ethics, politics, subjectivity and space. They are admittedly less clear in offering concrete guidelines for action in any determinant situation (Cloke, 2002). In a certain sense, this is precisely the point: the theoretical disruption of our ontological and political certainties can be a means to reinscribe a sense of responsibility toward the other, because it implies that we must weigh alternatives, make judgments and intervene in contexts whose complexity will always exceed predetermined formulations.

I do believe, however, that the argument presented here suggests certain lines of inquiry for the practice of human geography, and it is perhaps useful in closing to signal some of these briefly here. Put somewhat schematically, I would suggest that a poststructuralist understanding of ethics, politics and space implies two interrelated projects. First, a politics of deconstruction stands as a challenge to vigilantly call attention to the ways in which the infrastructure of modernity - its discourses, laws, and boundaries - has provided cover for the abrogation of our responsibility toward the other. In the first instance this means investigating the ways in which certain categories of identity have become naturalized, such that our ethical engagements with 'the face' become conditioned by specific kinds of social and cultural difference. Empirical investigations that highlight the relational nature of, for example, race, class or ethnic identity can shed light on the ways in which our 'place in the sun' is alwaysalready indebted to, and thus unsettled by, the presence of the other (Natter and Jones, 1997; Anderson, 2000a; Dwyer and Jones, 2000; Kobayashi and Peake, 2000). A related set of concerns emerges from an attempt to disrupt the metaphysics of 'ontopology', by tracing the ways in which spatial boundaries and divisions have been used to draw distinctions between self and other. From an historical perspective, for example, we can consider recent postcolonial interventions, which have illustrated the ways in which the spatial delineation of difference was instrumental to colonial projects, divisions which continue to have lasting impacts in the present (Noyes, 1992; Jacobs, 1996; Lester, 1998; Popke, 2003a). A second example concerns recent attempts to rethink Kantian statebased ethics, as evidenced by much recent writing on transnational migration, refugees and guest workers (Lawson, 2000; Anderson, 2000b; Dikeç, 2002; Dillon, 1999). Such 
work has insisted on a relational notion of citizenship and subjectivity, in order to reconceptualize an ethics based in conditions of what Derrida (2000a; 2000b) has recently figured as hospitality.

In addition to this deconstructive maneuver, we can add a second and related set of projects, aimed at reasserting our ethical relationship to distant others by opening ourselves to alternative ways of conceptualizing subjectivity and space. In this vein, a number of recent authors have explored the possibilities of constructing what might be referred to as an 'indigenous ethics' (Esteva, 1987; Rose, 1999; Sanders, 1999). Deborah Bird Rose, for example (1999: 181, 185), drawing upon the cultural repertoire of the Australian Aborigines, argues that 'listening to Indigenous people in an ethic of situated availability throws open a world of connection and responsibility ... [in which] a dialogical approach to connection impels one to work to realize the well-being of others'. This recognition of connection and responsibility has implications for the ways in which we approach a wide range of issues - from indigenous rights and land claims to struggles over the meaning of modernization and development (Sparke, 1998; Howitt, 2001; Suchet, 2002). To take just one example, this kind of 'situated' ethical commitment to community has been a powerful source of solidarity for subaltern groups seeking to confront the worst excesses of neoliberal globalization (Esteva and Prakash, 1998; Popke, 2003b).

Beyond these academic concerns, the theoretical interventions of poststructuralist ethics should be viewed as a challenge to invest our lives with forms of personal and professional engagement, to take seriously an obligation to act upon the irrecusable responsibility that arises from our being-in-community with others. 'The political', writes Nancy (1997: 88), 'is the place of the in-common as such ... the place of beingtogether.' To live ethically is to acknowledge this shared Being, and to participate in a collective spatial politics in which a commitment to the other is our abiding concern.

\section{Conclusion}

In a 1985 interview, Emmanuel Levinas was asked to describe the personal motivation for his philosophical investigations. He answered that he was responding to 'the fear of being in a world without novel possibilities, without a future of hope, a world where everything is regulated in advance ... [where] what is going to pass has in a sense already passed' (Levinas, 1985: 28). I believe that much the same sentiment lies behind the provocation that poststructuralist thought has posed to theories of ethics. The intervention of poststructuralism challenges us to think beyond a world in which the tocome' of the future is 'regulated in advance' by normative and juridical prescriptions. Taking this seriously means to abandon the traditions of modern ethical thinking, and the metaphysics of ontopology and sovereignty upon which they are based, in favor of an ethics and politics of deconstruction.

The ethos of deconstruction stands as an injunction to re-politicize the social, to actively engage and make judgments, and to reinscribe an irrecusable responsibility into the event of any decision. Following both Levinas and Nancy, we can figure this decision as an impossible demand to respect the alterity of others, to open ourselves to the fold of community constituted by our being-in-common-in-the-word. Within this fold, 'a space is offered whose spacing, each time, only happens by way of a decision. 
But there is not "a" decision. There is, each time, my own ( $a$ singular mine) - yours, theirs, ours. This is the generosity of being' (Nancy, 1993: 147). This generosity of collective being, which can also be named communism, can be retrieved from the ruins of metaphysics and modernity, but only on condition that we heed the provocation of poststructuralist thought, and cultivate an ethics of hospitality, within which the gift of space is offered unconditionally, and the arrival of the other calls our subjectivity to account.

\section{Acknowledgements}

I wish to extend my gratitude to Malcolm Cutchin and Richard Howitt for their generous and constructive readings of an earlier draft of this paper.

\section{References}

Anderson, K. 2000a: 'The beast within': race, humanity, and animality. Environment and Planning D: Society and Space 18, 301-20.

__ 2000b: Thinking 'postnationally': dialogue across multicultural, indigenous, and settler spaces. Annals of the Association of American Geographers 90(2), 381-91.

Barnes, T. 1994: Probable writing: Derrida, deconstruction, and the quantitative revolution in human geography. Environment and Planning A 26, 1021-40.

- 1996: Logics of dislocation: models, metaphors, and meanings of economic space. New York: Guilford Press.

Barnett, C. 1999: Deconstructing context: exposing Derrida. Transactions of the Institute of British Geographers NS 24, 277-93.

Bauman, Z. 1991: Modernity and ambivalence. Cambridge: Polity Press.

Braun, B. and Castree, N., editors 1998: Remaking reality: nature at the millennium. New York: Routledge.

Bridge, G. 2000: Rationality, ethics, and space: on situated universalism and the self-interested acknowledgement of 'difference'. Environment and Planning D: Society and Space 18, 519-35.

Campbell, D. 1998: National deconstruction: violence, identity, and justice in Bosnia. Minneapolis: University of Minnesota Press.

Campbell, D. and Shapiro, M. 1999a: Introduction: from ethical theory to the ethical relation. In Campbell, D. and Shapiro, M., editors, Moral spaces: rethinking ethics and world politics, Minneapolis: University of Minnesota
Press, vii-xx.

- , editors 1999b: Moral spaces: rethinking ethics and world politics. Minneapolis: University of Minnesota Press.

Caputo, J. 1993: Against ethics. Bloomington: Indiana University Press.

Cloke, P. 2002: Deliver us from evil? Prospects for living ethically and acting politically in human geography. Progress in Human Geography 26, 587-604.

Corbridge, S. 1994: Post-Marxism and postcolonialism: the needs and rights of distant strangers. In Booth, D., editor, Rethinking social development: theory, research and practice, Essex: Longman Scientific and Technical, 90-117.

_-_ 1998: Development ethics: distance, difference, plausibility. Ethics, Place and Environment 1(1), 35-54.

Cresswell, T. 1996: In place/out of place: geography, ideology, and transgression. Minneapolis: University of Minnesota Press.

Critchley, S. 1999: Ethics-politics-subjectivity: essays on Derrida, Levinas and contemporary French thought. New York: Verso.

Dear, M. 1988: The postmodern challenge: reconstructing human geography. Transactions of the Institute of British Geographers NS 13, 262-74.

-_- 2000: The postmodern urban condition. Malden, MA: Blackwell.

Derrida, J. 1976: Of grammatology (translated by G.C. Spivak). Baltimore: Johns Hopkins University Press.

1988: Limited inc. Evanston, IL: Northwestern University Press. 1990: Force of law: the 'mystical foundation 
of authority.' Cardozo Law Review 11, 919-1045.

1994a: Specters of Marx: the state of the debt, the work of mourning, and the new international (translated by P. Kamuf). New York: Routledge. - 1994b: The deconstruction of actuality: an interview with Jacques Derrida. Radical Philosophy 68, 28-41.

- 1995: Points: interviews, 1974-1994(edited by

E. Weber). Stanford: Stanford University Press. -_- 1996: Remarks on deconstruction and pragmatism. In Mouffe, C., editor, Deconstruction and pragmatism, New York: Routledge, 77-88.

- 1997: Deconstruction in a nutshell: a conversation with Jacques Derrida (edited by J. Caputo). New York: Fordham University Press.

- 1999: Marx and sons. In Sprinker, M., editor, Ghostly demarcations: a symposium on Jacques Derrida's Specters of Marx, London: Verso, 212-69.

-_- 2000a: Of hospitality (translated by R. Bowlby). Stanford: Stanford University Press. —- 2000b: Hospitality. Angelaki 5(3), 3-18.

Dikeç, M. 2002: Pera peras poros: longing for spaces of hospitality. Theory, Culture and Society 19(1-2), 227-47.

Dillon, M. 1999: The scandal of the refugee: some reflections on the 'inter' of international relations and continental thought. In Campbell, D. and Shapiro, M., editors, Moral spaces: rethinking ethics and world politics, Minneapolis: University of Minnesota Press, 92-124.

Dixon, D. and Jones, J.P. III 1998: My dinner with Derrida, or spatial analysis and poststructuralism do lunch. Environment and Planning $A$ $30,247-60$.

Doel, M. 1992: In stalling deconstruction: striking out the postmodern. Environment and Planning D: Society and Space 10, 163-79.

- 1994: Deconstruction on the move: from libidinal economy to liminal materialism. Environment and Planning A 26, 1041-59.

-_- 1999: Poststructuralist geographies: the diabolical art of spatial science. New York: Rowman and Littlefield.

Drabinski, J. 2000: The possibility of an ethical politics: from peace to liturgy. Philosophy and Social Criticism 26(4), 49-73.

Dwyer, O. and Jones, J. P. III 2000: White sociospatial epistemology. Social and Cultural Geography 1, 209-22.

Edkins, J., Persram, N. and Pin-Fat, V., editors 1999: Sovereignty and subjectivity. Boulder, CO: Lynne Reinner.

Esteva, G. 1987: Regenerating people's space.
Alternatives 12(1), 125-52.

Esteva, G. and Prakash, M.S. 1998: Grassroots post-modernism: remaking the soil of cultures. New York: Zed Books.

Ethics, Place and Environment 2001a: Theme section: landscapes and ethics (edited by $\mathrm{T}$. Unwin). Issue no. 4, 219-52.

2001b: Theme issue, no. 4(2).

Faulstich, P. 1998: Mapping the mythological landscape: an aboriginal way of being-in-theworld. Ethics, Place and Environment 1, 197-222.

Gibson-Graham, J.-K. 1996: The end of capitalism (as we knew it): a feminist critique of political economy. Cambridge, MA: Blackwell.

Harvey, D. 2000: Spaces of hope. Berkeley, CA: University of California Press.

— 1996: Justice, nature and the geography of difference. Cambridge, MA: Blackwell.

Hay, I. 1998: Making moral imaginations: research ethics, pedagogy, professional human geography. Ethics, Place and Environment 1, $55-76$.

Howitt, R. 2001: Frontiers, borders, edges: liminal challenges to the hegemony of exclusion. Australian Geographical Studies 39(2), 233-45.

— 2002: Scale and the other: Levinas and geography. Geoforum 33, 299-313.

Jacobs, J. 1996: Edge of empire: postcolonialism and the city. New York: Routledge.

Kant, I. 1939: Perpetual peace. New York: Columbia University Press.

Kirby, K. 1996: Indifferent boundaries: spatial concepts of subjectivity. New York: Guilford Press.

Kobayashi, A. and Peake, L. 2000: Racism out of place: thoughts on whiteness and an antiracist geography in the new millennium. Annals of the Association of American Geographers 90(2), 292-403.

Lawson, V. 2000: Arguments within geographies of movement: the theoretical potential of migrants' stories. Progress in Human Geography 24, 173-89.

Lester, A. 1998: Reformulating identities: British settlers in early nineteenth-century South Africa. Transactions of the Institute of British Geographers NS 23, 515-31.

Levinas, E. 1985: Ethics and infinity: conversations with Philippe Nemo (translated by R. Cohen). Pittsburgh: Duquesne University Press. 
_ 1989: The Levinas reader (edited by S. Hand). Cambridge: Basil Blackwell.

- 1991: Levinas. In Mortley, R., French philosophers in conversation: Levinas, Schneider, Serres, Irigaray, Le Doeuff, Derrida, New York: Routledge, 11-23.

- 1994: Outside the subject (translated by M. Smith). Stanford: Stanford University Press.

_- 1998: Entre nous: on thinking-of-the-other (translated by M. Smith and B. Harshav). New York: Columbia University Press.

Levinas, E. and Kearney, R. 1986: Dialogue with Emmanuel Levinas. In Cohen, R., editor, Face to face with Levinas, Albany: State University of New York Press, 13-33.

Low, N., editor 1999: Global ethics and environment. New York: Routledge.

Low, N. and Gleeson, B. 1999: Geography, justice and the limits of rights. In Proctor, J. and Smith, D., editors, Geography and ethics: journeys in a moral terrain, New York: Routledge, 30-43.

Nancy, J.-L. 1991: The inoperative community (translated by P. Conner, L. Garbus, M. Holland and S. Sawhney; edited by P. Conner) Minneapolis: University of Minnesota Press.

- 1993: The experience of freedom (translated by

B. McDonald). Stanford: Stanford University Press.

- 1997: The sense of the world (translated by J. Librett). Minneapolis: University of Minnesota Press.

_ 2000: Being singular plural (translated by R. Richardson and A. O'Byrne). Stanford: Stanford University Press.

Nast, H. 2000: Mapping the unconscious: racism and the Oedipal family. Annals of the Association of American Geographers 90, 215-55.

Natter, W. and Jones, J.P. III 1997. Identity, space, and other uncertainties. In Benko, G. and Strohmayer, U., editors, Space and social theory: interpreting modernity and postmodernity, Malden, MA: Blackwell, 141-61.

Noyes, J. 1992: Colonial space: spatiality in the discourse of German South West Africa 1884-1915. Philadelphia: Harwood Academic Publishers.

Ó Tuathail, G. 1996. Critical geopolitics. London: Routledge.

Ó Tuathail, G. and Dalby, S., editors 1998: Rethinking geopolitics, New York: Routledge.

Peet, R. 1998: Modern geographical thought. Malden, MA: Blackwell.

Perpich, D. 1998: A singular justice: ethics and politics between Levinas and Derrida. Philosophy Today Supplement, 59-70.
Pile, S. 1996: The body and the city: psychoanalysis, space and subjectivity. New York: Routledge.

Popke, E.J. 2003a: Managing colonial alterity: narratives of race, space and labor in Durban, 1870-1920. Journal of Historical Geography 29(2), in press.

- 2003b: The face of the other: Zapatismo, responsibility and the ethics of deconstruction. Social and Cultural Geography, in press.

Proctor, J. and Smith, D., editors 1999: Geography and ethics: journeys in a moral terrain. New York: Routledge.

Rose, D.B. 1999: Indigenous ecologies and an ethic of connection. In Low, N., editor, Global ethics and environment, New York: Routledge, 175-87.

Sanders, M. 1999: Reading lessons. Diacritics 29(3), 3-20.

Shapiro, M. 1998: The events of discourse and the ethics of global hospitality. Millennium 27(3), 695-713.

1999: The ethics of encounter: unreading, unmapping the imperium. In Campbell, D. and Shapiro, M., editors, Moral spaces: rethinking ethics and world politics, Minneapolis: University of Minnesota Press, 57-91.

Shields, R. 1992: A truant proximity: presence and absence in the space of modernity. Environment and Planning D: Society and Space 10, 181-98.

Sibley, D. 1995: Geographies of exclusion: society and difference in the West. London: Routledge.

Slater, D. 1997: Spatialities of power and postmodern ethics - rethinking geopolitical encounters. Environment and Planning D: Society and Space 15, 55-72.

Smith, D. 2000: Moral geographies: ethics in a world of difference. Edinburgh: Edinburgh University Press.

Smith, M. 2001: An ethics of place: radical ecology, postmodernity, and social theory. Albany: SUNY Press.

Soja, E. 1996: Thirdspace: journeys to Los Angeles and other real-and-imagined places. Cambridge, MA: Blackwell.

Sparke, M. 1998: A map that roared and an original atlas: Canada, cartography, and the narration of nation. Annals of the Association of American Geographers 88(3), 463-95.

Strohmayer, U. and Hannah, M. 1992: Domesticating postmodernism. Antipode 24(1), 29-55.

Suchet, S. 2002: 'Totally wild'? Colonising discourses, indigenous knowledges and 
managing wildlife. Australian Geographer 33(2), 141-57.

Unwin, T. 1999: The end of the Enlightenment? Moral philosophy and geographical practice. In Proctor, J. and Smith, D., editors, Geography and ethics: journeys in a moral terrain, New York: Routledge, 263-74.

Venn, C. 2000: Occidentalism: modernity and subjectivity. London: Sage.

Walker, R.B.J. 1999: Foreword. In Edkins, J., Persram, N. and Pin-Fat, V., editors, Sovereignty and subjectivity, Boulder, CO: Lynne Rienner, ix-xiii.

Whatmore, S. 1997: Dissecting the autonomous self: hybrid cartographies for a relational ethics. Environment and Planning D: Society and Space 15, 37-53.
Wilton, R. 1998: The constitution of difference: space and psyche in landscapes of exclusion. Geoforum 29(2), 173-85.

Wingenbach, E. 1999: Refusing the temptation of innocence: Levinasian ethics as political theory. Strategies 12(2), 219-38.

Wood, D. 2000: The international campaign against the Multilateral Agreement on Investment: a test case for the future of globalisation? Ethics, Place and Environment 3, 25-46.

Yapa, L. 1996: What causes poverty?: a postmodern view. Annals of the Association of American Geographers 86, 707-28.

Young, E.M. 1999: Far-fetched meals and indigestible discourses: reflections on ethics, globalization, hunger and sustainable development. Ethics, Place and Environment 2, 19-40. 
Copyright $\odot 2003$ EBSCO Publishing 